\title{
SOCIAL PEDAGOGY IN RUSSIA: TRENDS, PROBLEMS, IDEAS
}

\author{
Elena Sorochinskaya \\ Southern Federal University, Russia
}

\begin{abstract}
The given paper is concerned with holistic approach to social pedagogy in Russia. It covers the key trends in development of social pedagogy over the last 25 years. The main objective of the given paper is to give coverage to the researches that make significant contribution to development of social pedagogy in Russia. The author of the article highlights the key directions of the researches in the domain of social pedagogy, such as providing scientific grounds for the new direction of pedagogical knowledge, creation and development of schools of thought in social pedagogy, specific features of socialization of a growing personality, content and techniques of professional social education. The author states that only studying positive experience is the way to solving the problems that modern social pedagogy faces nowadays.
\end{abstract}

Keywords: helping pedagogy, paradigm, public assistance system, re-socialization, socialization, social education, social pedagogue, social pedagogy.

\section{Introduction}

In modern Russia, social pedagogy, treated as a social and humanitarian science that investigates problems of interrelation between personality and society, is one of the key directions in the development of modern pedagogical thought. Pedagogical activity in modern education is undergoing significant changes. In particular, we can witness reorientation from knowledge-based approach to personality paradigm, underpinned by humanistic values. In this respect, the key aspect of education is to encourage children to find their bearings in lives, in the field of self-organization rather than acquire sound factual knowledge in various subject areas and about different world phenomena.

The relevance and high priority of social pedagogical approaches has been stated by the Government of Russia and the mechanisms of education development are declared on the nation-wide scale. It is the question of sociocultural modernization of education, development of social competence and encouraging initiative of the Russian youth in various spheres of economy and social life. This approach also deals with creating social pedagogical conditions for preparation of children to professional identity and life self-determination; with interdepartmental integration in holistic (city, rural) educational space, social partnership and state-public poly-subject mechanisms of developing educational system in the open socio-cultural environment; social pedagogical 
support of family and personality at various stages of its development, groups of social risk and some other related issues.

Due to a number of complicated issues that underpin development of social pedagogy in Russia, it is relevant to give a review of the modern trends in this domain of national and cross-national studies. The main objective of the given paper is to give coverage to the researches that make significant contribution to development of social pedagogy in Russia. I am absolutely sure that only studying and sharing positive experience is the way to solving the problems that modern social pedagogy faces nowadays.

\section{Theoretical Grounds of Social Pedagogy in Russia}

Social pedagogy in modern Russia has recently faced a wide range of problems and challenges which didn't use to be on the agenda of society and are bred by new social conditions of life. Nowadays, a considerable number of topical issues are in the focus of its attention, namely: the problems of personal deadaptation and social maladjustment to ever changing conditions of life in society; lack of harmony in relations between a man and society; educational inconsistency and upbringing failures of some parents; interethnic tension, conflicts of interethnic kind; low level of culture, poor erudition and bad manners; dehumanization of public life; lack of continuity in various branches of industry and social sphere; overcoming youth infantilism; deformed relations within families and breaking good neighborly ties; social ill-being of children and family problems.

Social pedagogy in Russia as a science and branch of education elaborates progressive ideas of pedagogy that date back to the beginning of XXI century, integrating them with foreign experience. To certain extent, it has the status of developing natural experiment so far. Nevertheless, modern state of social pedagogy in Russia is characterized by a variety of approaches to definition of its frameworks, goals and objectives. Thus, social pedagogy is understood as one of the functions or directions of social work (I.A. Zimnaya, 1992), theoretical background of the trade "social work" (Bocharova, 2004), a part of general pedagogy focused on problems of social education (Mudrik, 2010; Semenov \& Wulfov, 1981).

In the framework of establishing social pedagogy as a science at the present stage of its development certain vectors can be mentioned: theoretical and methodological problems, in particular, definition of the subject of social pedagogy in the concept by A.V. Mudrik (Mudrik, 2010) which is based on the approach by German professor P. Natorp. Definition of socialization and the role of personality in this process are considered in researches by F.A.Mustayeva (Mustafayeva, 2001) and V.A.Nikitin (Nikitin, 2002).

Doctoral thesis by V.G.Bocharova became the first research which at the beginning of the 1990s enabled to lay foundation of social pedagogy in Russia 
in conditions of the new reality. Publication of the book "Pedagogy of Social Work" (Bocharova, 1994), supported by Soros Foundation, is the proof of this fact. In 2001 V.G.Bocharova together with I.A.Lipsky (Bocharova \& Lipsky, 2001) published a teaching manual called "The main directions of scientific researches in the field of social pedagogy". According to the authors, they include:

- $\quad$ socio-cultural concept of development of socially focused pedagogical phenomena, systems and processes;

- "personality - society - activity" based concepts of scientific knowledge and transformation of socially significant pedagogical practice;

- functional concept of methodological analysis of socially focused pedagogical knowledge;

- the concept of social development focused on personality and setting;

- problem and activity based concept of social development of various groups of the population;

- the concept of poly-functionality of socially focused pedagogical theory and practice;

- the concept of activity based social education and professional training in social sphere;

- the concept of finding scientific grounds fortransformation practice in society (Bocharova \& Lipsky, 2001).

Let us dwell onsome relevant issues which the school of thought headed by V.G.Bocharova sets forth. Primarily, they are as follows:

- studying methodological background of social pedagogy, structure and content of it treated as a scientific discipline;

- researches of theoretical and methodological grounds of social education of school children;

- research in to the features of social work in rural society (Bocharova, 2014).

At epistemological level, the optimal model of the development of social pedagogy as a science is connected with studying and scientific substantiation of the spheres of interaction with other sciences and scientific disciplines of higher methodological status (social philosophy, political science, sociology, social psychology, social medicine, social work, pedagogy, in particular, junogogy, andragogy, gerontology).

At the level of the world outlook studies, researches in to opportunities of social pedagogy in terms of getting knowledge about the world and transforming society in changing economic, political, social conditions become relevant.

At logical level, the framework of categories and concepts of social pedagogy is elaborated. 
At technological level, existing socially focused pedagogical technologies get piloted, while new ones targeted as various socially significant aspects are worked out and shaped.

At methodical level, work aimed at research into the structure, content, boundaries and rules for application of methods of practical, socially focused pedagogical activity, scientific research, and preparation of experts of social sphere as well as requirements to these methods will be continued (Bocharova $\&$ Lipsky, 2001).

To get insight of becoming and development of modern paradigm of social education, we have carried out theoretical analysis of the main researches which findings are reflected in manuals, monographs and dissertations of the end of the XX - beginning of the XXI centuries. Post-soviet period in Russian social pedagogy is associated with emergence and active development of a number of scientific schools, for example, the school of thought headed by S.A. and I.V.Mavrin (Omsk); Novosibirsk scientific school (headed by prof. T.A. Romm and Z.I.Lavrentyeva); Chelyabinsk scientific school (prof. R.A.Litvak); Kostroma scientific school (prof. N.F. and V.M.Basov, A.G.Kirpichnik); SaintPetersburg scientific school (prof. S.A.Raschetina); Tula scientific school (V.A.Fokin); Mari scientific school (N.S.Morova); Yaroslavl scientific school (prof. M.I.Rozhkov); southern scientific school (prof. T.D.Molodtsova, E.N.Sorochinskaya): Moscow scientific school (prof. A.V.Mudrik, L.V.Mardakhayev).

An outstanding researcher of the Russian Academy of Science, doctor of pedagogical sciences M.P. Guryanova has also made a great contribution to the development of socially significant pedagogical problems. Conceptual approaches to teaching and developing viability of rural school pupils are in the focus of attention of M.P. Guryanova (Guryanova, 2014).

Social education and upbringing seen as "assisting activity" are referred to as socially pedagogical help, socially-pedagogical rehabilitation, correction or social support in various research papers. In other words, scientists are concerned with technologies aimed at organization of help (pedagogically focused, expedient system of public aid) for inclusion of an individual in to social life. As for the main institutions that render social education, they include specialized services, establishments, rehabilitation centers and some other similar institutions (Nikitin, 2002).

A.V.Mudrik was the first to offer the new, updated paradigm of social upbringing. The scientist worked out the theory of social upbringing in the context of cultural shock which is understood as the conflict between old and new cultural norms and orientations of society. It is the conflict between the society that an individual has left and the new kind of society where he/she has arrived. In the monograph "Socialization of an Individual" he supplements the features of the issue under study with the fact that social education and upbringing can take place in criminal and totalitarian, political and quasi- 
religious communities. In this connection, de-social and counter-social education types are mentioned (Mudrik, 2010). The renewed paradigm of social education sets forth the idea of multifacetedness of social environment of a person which is revealed in the system of interpersonal relations and communications, in the activity of a person in his/her setting.

The problem of classifying diverse aspects of development of social pedagogy and professional social education on the basis of historical analysis of pedagogical reality in order to forecast their development is still insufficiently resolved. Singling out stages in development of social pedagogy and social professional education and their system analysis make it possible to predict prospects of development of the given field of pedagogical science.

\section{Professional Social Education: the key priorities}

Professional social education is in its early days in Russia and is the subject of research of many pedagogues. As for the content of professional social education, it includes: knowledge about individual and group behavior of people (about relations of an individual with social structures and institutions, about participation of a person and public structures in social processes, knowledge of laws and norms of social processes, etc.); knowledge of the theory and practice of social work (principles, means, methods, techniques employed in practical work for achievement of general goals of social well-being or specific objectives for each separate case); particular professional knowledge (specific technologies of social work);

In theoretical aspect, it is necessary to lay grounds for the development of pedagogical technologies of professional social education, first of all, to provide integration of theory and practice. Modular-based training should be based on working out modular blocks of academic courses for experts of social sphere which eventually leads to breaking barriers between different subjects, courses, levels.

In the nearest future we should develop effective technologies and principles of professional training of social pedagogues. Technologies like that include competence-based approach; continuity principle; multi-levelness and gradualness; diversification. They will help to provide development of the basic system of professional social education as long as other principles of development of modern system of professional education are taken into account. These fundamental milestones of professional education are: encouraging initiative; "case work" or social therapy; self-education and self-reflection.

Theoretical background of professional social education in the Russian Federation is based on the system of knowledge about the foundation and structure of social pedagogical theory, principles, approaches and ways of getting the knowledge that reflects social reality as well as the system of acquiring this knowledge and providing grounds for establishing the logic and 
methods for estimating the quality of social pedagogical education (Sorochinskaya, 2014).

Some mainstream trends in development of the theory of professional social education typical for the end of XX - beginning XXI centuries can be singled out. They include granting official status to preparation of social pedagogues as a special direction in professional education; increased role of practical activities in preparation of social pedagogues; integration of social pedagogical education into the complete system of pedagogical education in the country; interdepartmental, continuous, poly structural nature of professional preparation of social pedagogues (Aliyeva, 2011; Lefter, 2012).

During the specified period a number of concepts of social pedagogy in Russia were worked out. Let us mention the most significant ones (Sorochinskaya, 2012):

1) the concept of professional readiness that considers professional preparation of social pedagogues as the process of developing pedagogue's personality and social professional position of an expert proceeding from the synthesis of moral, psychological, theoretical and practical (technological) aspects of readiness which provides the necessary level of their professional competence; the concept of regional socially-pedagogical education is based on the complex, multi-level, integrative approach; the key idea is to take into account social order and labor market demand for training personnel resources for enterprises, establishments, firms and different social institutions of the region relying on teaching staff called to provide academic process according to the state standards;

2) "the concept of socialization" based on professional training of social pedagogues for transferring social knowledge and development of socially significant skills that promote socialization of a child; fostering socially significant qualities of children's personalities necessary for successful socialization;

3) "the concept of social didactics" that considers vocational training of social pedagogues as their preparation for social pedagogical support, assistance and consultation of a child proceeding from integration of domestic and foreign experience; it also deals with study of interference of socialization and education by means of analysis of social interaction, communication and behavior of pupils in academic setting; analysis of aggressive behavior of children as a socially pedagogical problem and search for ways to overcoming it; the concept of general professional readiness (as in the case of orthodox higher educational institution);

4) "the concept of social education" which is understood as creation of favorable nurturing conditions for providing positive development of 
an individual and a group of future social teachers in their professional training.

Analysis of becoming and development of the theory and practice of vocational training in European countries (Germany. Lithuania, Latvia) proves that they have well-developed sector of preparation of experts to work with physically challenged children, prevention of deviant behavior of children and youth, purposeful work with family, various effective technologies of sociallypedagogical work (Majauskiene, 2008; Juris, 2012; Lelugene, 2014)

\section{Conclusion}

Professional preparation of social teachers can be of high quality and effective only if it is based on the consistent theoretical approaches. In this connection, they are supposed to prove to be real insight into specific aspects of professional work of a social pedagogue, the heart matter of social pedagogy as a branch of scientific knowledge and shape the kernel of theoretical preparation of social pedagogues. Integrating role of practice in professional preparation of social teachers is also the issue of special importance.

Professional becoming and further development of the institutions of social pedagogy in Russia assume consecutive solution of a number of problem sat the state, nation-wide level. As the given research has shown, a great deal of unsolved problems mentioned above constrain and make efficient use of all the opportunities offered by this institution quite difficult in modern national practice of social work.

The modern condition of the theory and practice of Russian social pedagogy is characterized by a great variety of approaches to definition of its heart matter, tasks and objectives. Since the beginning of the 1990s, some models based on continuity of the historical experience of Russian charity institutions and development of public tutorship were defined. Modifying European and American models of socially-pedagogical work and combined models combining the elements of both are actively elaborated. Social policy of childhood at the state level contributed to creation of the infrastructure for the state support of family, motherhood and childhood. The following tendencies of development of the theory of professional social education in Russia at the end of XX - beginning XXI centuries can be referred to: registration of vocational training of social teachers in the special direction of education; high priority of practical activities in preparation of social teachers; integration of sociallypedagogical education into a complete system of pedagogical education in the country; giving to vocational training of social teachers of interdepartmental, continuous, poly-structural nature.

Professional becoming and further development of institution of social teachers assumes development of network interaction as important source of exchanging positive experience in conditions of social differentiation, development of joint complex programs that can effectively counter the 


\section{SOCIETY. INTEGRATION. EDUCATION. Volume III}

challenges of the XXI century and lead to improvement of quality professional socially - pedagogical education.

\section{References}

Aliyeva, S.V. (2011). Development of social pedagogy and system of professional education of experts of social sphere in modern Russi). Candidate's Thesis in Pedagogy. Moscow.

Bocharova, V.G. (1994). Pedagogy of Social Work. Moscow.

Bocharova, V.G. (2004). Social pedagogy: monograph. Moscow: humanitarian publishing center VLADOS.

Bocharova, V.G. and Lipsky, I.A. (2001). The main directions of scientific researches in social pedagogy. Moscow: published by SSoPiR of the Russian Federation.

Guryanova, M.P. (2014). Institution of social pedagogues in modern Russia: system analysis. Proceedings of the International conference "Socially-pedagogical professional education in the global world: modern priorities". pp. 183-192. Edited by V.G. Bocharova. Institute of Social Pedagogy of the Russian Academy of Science. Moscow. Saint-Petersburg: Nestor-Irtoriya.

Juris, Z. (2012). Higher education provided by the service warranty. Society. Integration. Education. Proceedings of the International Scientific Conference. Volume II. "Social and special pedagogy, health and sports,overview. May 25-26 2012. Rezekhe.

Lefter, A.M., (2012). Development of the theory of professional education of social pedagogues in Russia. Candidate's Dissertation in Pedagogy. Moscow.

Lelugene, I.Y. (2014). Historical roots and modern trends of development of the institution of social pedagogues in Lithuania.Proceedings of the International conference "Sociallypedagogical professional education in the global world: modern priorities". pp. 223237. Edited by V.G. Bocharova. Institute of Social Pedagogy of the Russian Academy of Science. Moscow. Saint-Petersburg: Nestor-Irtoriya.

Majauskiene, L. (2008). Search for common structureof activity ofschool of socialpedagogue in different context (comparison of Lithuanian and German cases). Doctoral dissertation. Kaunas University of Technology, 2008.

Mudrik, A.V. (2010). Socialization of an individual: teaching manual. $3^{\text {rd }}$ edition: corrected and added. Moscow: MPSI; Voronezh: MODEK.

Mustafayeva, F.A. (2001). Basics of social pedagogy. Moscow: published by AkademicheskyProjekt.

Nikitin, V.A. (2002). Social work: issues of theoretical kind and of specialists' preparation. Moscow: publishedbyMoscowPsychologicalandSocialInstitute.

Sorochinskaya, E.N. (2012). Scientific school of social pedagogy. Regional experience. LAPLAMBERT. Academic publishing Saarbrucken. Lap-Lambert/Saar-Bruckner.

Sorochinskaya, E.N. (2014). The problem of development of national professional socially pedagogical education in the realities of the XXI century. Proceedings of the International conference "Socially-pedagogical professional education in the global world: modern priorities". pp. 26-38. Edited by V.G. Bocharova. Institute of Social Pedagogy of the Russian Academy of Science. Moscow. Saint-Petersburg: NestorIrtoriya.

Sorochinskaya, E.N. (2014). Prognostic mission of sociological knowledge in development of the theory of social pedagogy. In: Social pedagogy in Russia: on the cutting edge of time: monograph. pp. 175-188. Edited by M.P. Guryanova. Institute of Social Pedagogy of the Russian Academy of Science. Moscow. Saint-Petersburg: Nestor-Istoriya.

Wulfov, B.Z. and V.D. Semenov (1981). School and social environment: interaction. Moscow: published by Znaniye.

Zimnyaya, I.G. (1992). Social work as a professional activity. SocialWork. 1992, Issue 2. 